\title{
Legal Harmonization of Civil Dispute Settlement Use for Legal Unification
}

\author{
HM Hosen ${ }^{1, *}$ Rosmidah ${ }^{2}$ \\ ${ }^{2}$ Faculty Of Law, Jambi University \\ ${ }^{*}$ Corresponding author. Email: rose andy64@yahoo.co.id
}

\begin{abstract}
The current civil dispute resolution law is still pluralistic and spread in various laws and regulations, however, it is still maintained as a guide in examining, hearing and deciding civil cases in Indonesian courts. Legal pluralism can cause conflict of norms and create legal uncertainty in the resolution of civil cases. Therefore, can the legal arrangements for resolving civil disputes in Indonesia be harmonized in the context of legal unification? What is the juridical, philosophical and sociological rationale for the need to harmonize civil dispute resolution laws? This research is a normative legal research with a statutory approach, a historical approach, a conceptual approach, and a comparative approach. Research result shows that the law of civil dispute resolution can be harmonized to realize legal unification since various kinds of regulations can cause multiple interpretations, is strenuous to realize justice and legal certainty and cause disharmony of regulations. The existing civil procedural law provisions were a product of the Dutch East Indies government and could no longer accommodate the development of society, developments in science, technology and information. Juridically, the current content of legal norms or rules for resolving civil disputes is no longer accommodating the development of society hence it needs to be evaluated. Philosophically, the new concepts and legal principles for civil dispute resolution must be able to respond to the development of society. Sociologically that the presence of new laws and regulations is not challenged by the community. Therefore, harmonization of civil dispute resolution law is needed in the framework of unification of civil procedural law.
\end{abstract}

Keywords: Legal harmonization, civil disputes, legal unification.

\section{INTRODUCTION}

The flow of globalization marks the progress of a country and has implications for the development of science and the speed of technology. Both of the aspects are a manifestation of the advancement of a country's civilization and has positive and negative implications. The development of science and technology leads new forms of legal relations and new legal institutions in the field of business and civil law. Along the way, the new legal relationship and the new legal institution can open onto the disagreement that can lead to both civil and criminal disputes.

The emergence of legal relations and new legal institutions, indeed, requires regulations as a forum for settlement in the event of a dispute. Civil disputes must be resolved so that there is no further conflict. Meanwhile, the existing legal institutions for resolving civil disputes have not yet led to legal unification.
Civil dispute resolution is an attempt by the disputing parties to end conflicts or disputes that occur in society. Resolving civil disputes that occur in society today requires complete regulation, regulating all forms of business and civil disputes. The laws and regulations that serve as legal guidelines in resolving civil disputes so far have disharmony between various legal provisions for civil dispute resolution. In addition, there are various statutory provisions which regulate the same thing or substance differently and cause multiple interpretations and uncertainties.

Various regulations have been issued by the government in the form of Laws, Government Regulations, PERMA relating to the settlement of civil disputes in Indonesia, but still have legacy regulations from the Dutch Government. These regulations have undergone many developments, especially the material they regulate, due to the expansion of legal relations and new legal institutions in the field of civil law. 
Various regulations governing civil dispute resolution procedures are a consequence of the dynamics of the development of legal relations and legal events in society, both in national and international scope, as globalization of community relations and globalization of trade have become a reality, not an option.

The law for resolving national civil cases, which is a legacy of the current Dutch government, is felt to be inadequate in ensuring the implementation of material civil law. The development of events and new legal institutions are not accommodated in these regulations. Exceedingly, concerning special civilizations have been formed to accommodate the development of legal relations and national, regional and international legal events. Dispute resolution is no longer only through intermediary judges in court, but dispute resolution based on the philosophy of justice in many rooms can be carried out of the court, either through adjudication or nonadjudication, for example through arbitration, mediation, conciliation. and others.

Thus, the civil dispute resolution law that will be established should cover all provisions regarding the resolution of various civil disputes both in court and outside the court, both disputes that occur within the boundaries of national jurisdictions, as well as regional and international jurisdictions. It can be said that the new civil dispute resolution law is no longer identical to the definition of civil procedural law as in HIR / RBG but rather a national civil procedural law that unites all provisions of civil procedure which have been widely spread in several laws and regulations. There is a civil procedural law which is regulated together with the material law, and some are even integrated into criminal and administrative provisions, for example Law No. 32 of 1999 concerning Management and Protection of the Environment.

According to Otto Hasibuan that "it is necessary to have a national civil procedural law, since there are problems in the civil procedural law that are still valid, namely, the inconsistency of a special power of attorney, the relevance of the oral form of the lawsuit, the technical online case examination, the lawsuit against parties abroad, summoning the parties in litigation, stamp duty in the lawsuit[1].

Thus the law of civil dispute resolution can be said to be a legal rule that determines the judicial institution which is authorized to settle cases, the parties entitled to file disputes, the stages of civil dispute resolution, both in court and outside the court, how to file rights claims, how to register a lawsuit, examine and decide and implement decisions regarding disputes that occur in national, regional and international jurisdictions, as well as the need for filing cases electronically. All these questions need to be elaborated in a civil dispute settlement law. The questions are: Can the legal arrangements for civil dispute resolution in Indonesia be harmonized in the framework of legal unification? What is the juridical rationale, philosophical and sociological the need to harmonize civil dispute resolution laws?

\section{LITERATURE REVIEW}

\subsection{Civil Dispute Resolution in Indonesia}

Indonesia is a country based on law, as the consequence, the law is placed in all principles of community and government activities in the life of the state and society. So that all actions of individuals and groups of people must be directed in accordance with those determined by the regulations made by the government. The existence of law in this case is intended as a means to carry out social supervision, namely where the law is an instrument used to influence people to behave in accordance with the expectations of society which have been established by the State and law as a means of carrying out social change[2].

According to Leon Duguit, "the law is defined as the behavior of community members, the rules which can be used at a certain time by a society as a guarantee of the common interest and if they are violated it creates a joint reaction against the person who commits the violation[3]. This is in line with Michael Hager's thinking about the function of law that serves three sectors, namely: first, law as a means of ordering, means that law can create a framework for political decision making and dispute resolution that may arise through procedural law and can lay the legal basis (legitimacy) for power holders, second, laws as a means of balancing the law can maintain balance and harmony between the interests of the State or public interests with personal interests, third, laws are catalysts, the law can help to facilitate the process of change through legal reform (law reform) with the help of creative personnel in the legal profession[4].

In terms of law as a means of controlling community behavior and as a means of resolving a dispute or conflict, it means that a legal norm is needed, where the norm must be able to move dynamically according to space and time as well as the development of society and technology, meaning that the regulation can keep up with changes and the progress of time and technological speed.

Different interests in society often lead to disputes / conflicts. "Conflict or dispute is a situation and condition in which people experience disputes that are factual as well as disputes that exist in their perceptions only[5]. Conflicts or disputes that occur in the community are usually resolved by tradition first with the tradition elders. However, there was dissatisfaction from the parties, so it was resolved through the court.

Meanwhile, dispute resolution is a settlement of a case carried out between one party and another. Settlement of civil disputes consists of two ways, namely through litigation (court) and non-litigation (outside the 
court). In the dispute resolution process through litigation is the last means (ultimum remidium) for the disputing parties after the settlement process through non-litigation does not produce results[6].

Various studies have been conducted regarding the settlement of civil cases, both settlement of cases through court or settlement of cases outside the court with various regulations that cover it. Settlement of civil cases outside the court as has been done by Permono, that the settlement of civil cases, especially land can be done at the local Land Office, but often raises problems, namely the disputing parties consider this out of court settlement to be unsatisfactory[7].

Settlement of civil disputes through courts is taken by the disputing parties as a last resort if deliberation fails to produce satisfactory results. The legal provisions for resolving civil cases in court are pliuralistic and are still based on the HIR / RBG and other regulations issued by the Supreme Court. Although there are several obstacles, such as the lack of justice and legal certainty, until now these regulations are still being used in civil case proceedings.

The government has also issued regulations related to simple dispute resolution in court, namely PERMA No. 2 of 2015 concerning Procedures for Settlement of the Simple Lawsuit. According to M. Hosen that the existence of a simple, fast and low-cost judicial principle is actually in order to eliminate concerns about law enforcement from foreign investors who invest in Indonesia, as well as concerns from other countries which are Indonesian business partners in the implementation of free trade, and at the same time the most important thing is to reduce the accumulation of civil cases in the Supreme Court, especially at the level of cassation[8].

The objective of civil dispute resolution law is none other than to achieve justice and legal certainty. The realization of justice must be preceded by legal certainty so that it is necessary to have a civil procedural law that is unified or not too many multi-interpretations, hence in the end a fair judge's decision can be found. So, the pluralistic civil procedural law in its application has many obstacles, does not reflect legal certainty and is very difficult to achieve therefore, it is necessary to have a unity of civil procedural law (legal unification)[9].

Along with the development of procedural law in Indonesia and public dissatisfaction with court proceedings that are unable to embrace all the interests of the litigants, an out-of-court case resolution method is developed which is determined by the disputing parties, whether in place, time, cost or mediator.

According to the Arbitration Law and Alternative Dispute Resolution, dispute resolution through nonlitigation (outside court) consists of 5 ways, namely:
Consultation: an action taken between one party and another party that is a consultant party.

Negotiation: settlement outside the court with the aim of reaching mutual agreement on the basis of more harmonious cooperation.

Mediation: settlement through negotiations to reach an agreement between the parties, assisted by a mediator.

Conciliation: dispute resolution is assisted by a conciliator whose function is to mediate between the parties to find a solution and reach an agreement between the parties.

Expert Assessment: expert opinion on something that is technical and in accordance with their field of expertise.

Thus, the settlement of disputes in the civil sector in Indonesia, apart from through the courts, parties seeking justice and legal certainty can also resolve civil cases out of court. There are several options that can be chosen by the disputing parties and in determining these choices are based on the agreement of the disputing parties in the form of a written agreement, meaning that this choice is stated in the legal relationship clause or outside the legal relationship clause.

Currently the government is developing a peace process as referred to in Article $130 \mathrm{HIR}$ which is integrated with the trial process, namely through mediation. This means that the trial process will not be continued if the parties have not gone through the mediation process first. This mediation has been developed for all civil cases such as land disputes, inheritance, divorce and environmental disputes.

\subsection{Harmonization of Law in Indonesia}

Various laws and regulations in Indonesia that regulate how to resolve civil disputes which can certainly lead to disharmony which results in:

a. There are differences in interpretation in the implementation;

b. The emergence of legal uncertainty;

c. Legislation is not implemented effectively and efficiently;

d. Legal dysfunction, meaning that the law cannot function to provide behavioral guidelines to the community, social control, dispute resolution and as a means of orderly and regularly social change[10].

Prevention of disharmony can be carried out through harmonization of drafting laws and regulations. Based on the analysis of the National Law Development Agency of the Ministry of Law and Human Rights, "legal harmonization is a scientific activity towards a written law harmonization process which refers to philosophical, sociological, economic, and juridical values". Thus, the meaning of law in the definition of legal harmonization contains a meaning that is still abstract and broad, therefore the definition of legal harmonization is meant 
as all statutory regulations, both laws, Presidential Regulation, PERMA and so on.

According to Sapto Budoyo, "legal harmonization is an effort or process that aims to overcome differences, contradictory matters and irregularities. Efforts or processes to realize the harmony, suitability, harmony, suitability, balance between legal norms in legislation as a legal system within a single national legal framework[11].

Thus legal harmonization is an effort of legal reasoning or action to carry out legal reasoning or (alignment / suitability / balance) written law with reference to philosophical, sociological, including economic and juridical values. According to law, the term harmonization of the law describes a broad meaning, covering all the provisions of the legislation. Harmonization of law is "harmonization of statutory regulations, namely the process of harmonizing and harmonizing between statutory regulations as an integral part or sub-system of the legal system in order to achieve legal objectives[11].

According to Sapto Budoyo, the harmonization of laws and regulations can be divided into vertical and horizontal. The distribution is based on the position between one statutory regulation and other laws and regulations. Vertical harmonization is the harmonization of laws and regulations with other laws and regulations in a different hierarchy. Meanwhile, horizontal harmonization is the harmonization between statutory regulations and other laws and regulations in the same hierarchy[11].

Harmonization of the legal system for resolving business and civil disputes nationally is intended to lay the same mindset as the basis for resolving business and civil disputes, the preparation of the legal system is intended as a reference for the national legal system (legal system harmonization), according to Kusnu Goesniadhie S., which includes:

a. The legal substance component or legal system consists of an external legal system, namely statutory regulations, unwritten law including customary law and jurisprudence, as well as an internal legal order, namely the legal principles underlying it;

b. The legal structure component and its institutions (legal structure) consists of various institutional bodies or public institutions with their officials; and

c. The legal culture component (legal culture) includes the attitudes and behavior of officials and citizens of the community with respect to other components in the process of organizing social life[12].

Reffereing to those components, the ideal step that must be applied in forming legal harmonization is to understand the main points of the existing legal system within the framework of the national legal system which includes "the legal substance component of the legal structure and its institutions and components of legal culture. Thus, the harmonization of the national legal system must take into account the linkage of the three components of the legal system in the framework of the national legal system[13].

John Henry Merryman, put forward three legal reform model frameworks which are referred to as legal reform models, "tinkering, following and leading". In terms of the legal reform model framework, Merryman is applied as a model framework for legal harmonization, so theoretically there are three models of legal harmonization, namely tinkering harmonization, following harmonization and leading harmonization. In terms of the legal harmonization, model framework is derived from the legal reform model, tinkering, following and leading.[14]

\section{RESULTS AND DISCUSSION}

\subsection{Harmonization of Civil Procedure Law in the Context of Legal Unification.}

Civil procedural law regulates the rights and obligations of proceeding or how to defend material civil law so that civil procedural law is procedural and not as substantial as in material civil law. Therefore, if it is said that judges are obliged to explore the law in society, it implies that judges must have the expertise to explore legal values that exist in society as long as it is related to material law.

Civil procedural law in theory and practice is a rule that governs how to carry out penalties for violations of civil rights that occur in accordance with the provisions in material law, so the nature of civil procedural law is to carry out penalties for violators of individual civil rights and / or against other parties in accordance with the provisions of laws and regulations in civil material law hence it can be enforced by force through the authority of the court.

Concretely, the nature of civil procedural law is to maintain material civil law. Initially, the nature of civil procedural law was to regulate, but when it is used, it becomes coercive[15]. When the parties go to court, all are bound by the rules including the judge, therefore the main characteristic of procedural law is binding or rigid for the person using it, hence procedural law cannot be deviated[16].

Civil procedural law which is also known as formal law is a legal regulation whose function is to regulate how to maintain and conserve material civil law[17]. Civil Procedural Law or civil dispute resolution law has dimensions and correlations regarding matters:

a. Administrative procedures, how a person submits a case to court;

b. The process by which a civil case begins to be heard by a judge;

c. Procedure for calling the parties;

d. The way a judge works in deciding civil cases;

e. What is the stage and implementation of the judge's decision (execution).

The statutory provisions regulating actions in civil dispute resolution are contained in various statutory 
provisions, which regulate various things or substances that resemble different things, giving rise to multiple interpretations and legal uncertainty. Since the main source of law for civil case settlement is the HIR and RBG, legal developments that occur are accommodated through technical regulations and policy regulations issued by the Supreme Court so that judges in carrying out their duties can be legally accountable. Enforcing the law must also be based on the law because the task of the court is to provide legal services and justice to the people who need them, not social services in general, because the court is not an executive agency but a judicial institution whose independence of power must be maintained. Therefore, it is not true if judges in completing their judicial duties are given a deadline since the judge's duties are not the same as the work of journalists who are chasing to be published in newspapers or magazines. However, this does not mean that judges can delay the time of the trial which is not clear, so that the principles of simple, fast and low cost cannot be implemented and applied by judges in hearing cases.

The laws and regulations governing civil dispute resolution have developed, but in patchy form, including:

1. Het Herziene Inlandsche Reglement (HIR)

2. Rechtsreglement voor de Buitengewesten (RBg)

3. Civil Procedure Code

4. Commercial Law Code.

5. Algemene Bepalingen van Wetgeving (AB)

6. Law No. 30 of 1999 concerning arbitration and alternative dispute resolution and

7. Law No. 48 of 2009 concerning Judicial Power.

8. Law Number 7 of 2012 concerning Social Conflict Management.

9. Presidential Instruction No. 1 of 1991 concerning Compilation of Islamic Law.

10. Jurisprudence as a living source of law.

11. Regulation of the Supreme Court of the Republic of Indonesia, namely regulations containing provisions that are procedural law.

The number of legal sources for settling civil cases in Indonesia today is due to:

a. During the era of the Dutch East Indies Government, at the legal level there was a different legal treatment for Madurese Javanese from those outside Madurese Java. For people in Java, Madura, the source of law for civil case settlement uses HIR, while outside Java uses $\mathrm{RBg}$.

b. In Indonesia, currently there are four kinds of judicial environment, namely general courts, religious courts, military courts and state administrative courts. Of the four courts, only the military court specifically handles criminal cases, while the other three courts resolve civil cases using the HIR and RBg, but specifically the religious courts also recognize the legal sources for settling civil cases in the form of the Koran and Hadith. c. Empirically, many people who wish to receive justice experience a long and convoluted judicial process. The lengthy procedure in civil case investigation procedures clearly does not reflect simple principles,fast and low cost; The resulting settlement places winners and losers facing each other, and often creates hostility even though it is written in the form of a judge's decision which has binding legal force for the parties. The principle of simple, fast and low cost is one of the judicial principles mandated by Law Number 48 of 2009 concerning Judicial Power. In line with this, the Supreme Court has issued Supreme Court Regulation Number 2 of 2015 concerning Procedures for Settling a simple lawsuit which has been amended by PERMA No. 4 of 2019.

Regulation of the Supreme Court (hereinafter abbreviated to as PERMA) is one of the statutory provisions other than those provided for in the provisions of Article 7 paragraph (1) of Law No. 12 of 2011 concerning the Establishment of Legislation. PERMA in the Indonesian legal system is recognized for its position and has legal force that can be binding as long as it is ordered by the provisions of higher legislation or other provisions created based on the authorization of the maker. The authority of the Supreme Court in making PERMA is regulated in Article 79 of Law Number 14 of 1985 concerning the Supreme Court, namely, "The Supreme Court can further regulate matters necessary for the smooth running of the judiciary if there are things that are not sufficiently regulated in Law invite this. " Elucidation of Article 79 of Law no. 14 of 1985 is as follow:

"If in the course of the judiciary there is a legal deficiency or void in a matter, the Supreme Court has the authority to make regulations as a complement to fill the gap or void. With this Law, the Supreme Court has the authority to determine the way to resolve an issue that has not been or is not regulated in this Law. In this case, the regulations issued by the Supreme Court are differentiated from those drawn up by legislators. Judicial administration as referred to in this law is only part of the overall procedural law. Thus, the Supreme Court will not interfere with and go beyond the regulation of the rights and obligations of citizens in general, nor will it regulate the nature, strength, means of proof and judgment or the distribution of the burden of proof. "

Thus, the function of PERMA is to fill in deficiencies or gaps in the law in carrying out judicial practices to prevent disparities in providing justice that causes legal certainty to not materialize. PERMA is basically a form of regulation that contains procedural law provisions. PERMA is a special regulation so that it is subject to the principle of lex specialis derogat legi generalis. 
This can lead to legal disharmony which is reflected in the conditions conveyed by Kusnu Goesniadhie:

a. Too many laws and regulations are being enforced.

b. Differences of interest and interpretation.

c. The gap between technical understanding and legal understanding of good governance.

d. Legal constraints faced in the application of laws and regulations, which consist of regulatory mechanisms, regulatory administration, anticipation of change, and law enforcement.

e. Legal obstacles faced in the application of laws and regulations, namely in the form of overlapping authorities and conflicts of interest[18].

According to Lon Fuller, there are eight good legal criteria, namely:

1. The law must be obeyed by all people, including the authorities of the State;

2. Laws must be published;

3. The law must apply forward, not retroactive;

4. The rule of law must be written clearly so that it can be recognized and applied correctly;

5. The law must avoid contradictions;

6. The law should not oblige something that society cannot fulfill;

7. The law must be constant so that there is legal certainty, but the law must also be changed if the political and social situation has changed;

8. The actions of government officials and law enforcers must be consistent with the applicable law[19].

Legislation that is good and does not cause confusion in society is the foundation of a rule of law that will guarantee the rights of citizens, limit the power of the ruler, guarantee freedom and legal justice in order to create social welfare.

The objective of civil dispute resolution law is none other than to achieve justice and legal certainty. The realization of justice must be preceded by legal certainty so it is necessary to have a civil procedural law that is unification or not too many multi-interpretations, hence in the end a fair Judge's decision can be found. The pluralistic civil procedural law in its application creates many obstacles, does not reflect legal certainty and is very difficult to achieve justice, so it is necessary to have a unity of civil procedural law (legal unification)[20].

The new civil dispute resolution law or civil procedural law is a revised law of dispute resolution that was previously spread in various regulations due to developments in law or community life that need to be regulated by law.

Legal development cannot be separated from the development of society, where at this time various new phenomena have emerged as a result of advances in technology and information marked by the era of informatics technology in cyberspace with the presence of an interconnected network (internet) that uses paperless communication (paperless document)[21].

Legal development is also closely related to the growth of science today which affects the life of the global community, among others, with advances in technology and information and the rapid use of information technology.

The development of legal substance in Indonesia is still ongoing (never ending process) as statutory regulations are one of the main pillars of the national legal system. However, there are still some legally problematic laws and regulations, both because of the substance, process and procedure, as well as the legal drafting aspects. There are at least three main problems in this area, namely: (i) overlapping and inconsistency of laws and regulations; (ii) the formulation of laws and regulations is unclear; and (iii) law implementation is hampered by its implementing regulations.

The mentioned problems, among others, are caused by the process of forming laws and regulations which ignore the importance of deepening the content, coordination, synchronization and harmonization with other laws and regulations. Therefore, one of the priorities that must be carried out in the framework of developing national law is harmonizing statutory regulations.

Realizing the codification and unification of civil dispute resolution law will be able to guarantee the realization of legal certainty and justice in the life of the state. In addition, codification and unification of law will serve as a guideline for the development of dynamics towards legal harmonization of Civil dispute resolution. The changes made do not mean that all of their substance is new, but that some existing regulations need strengthening and sharpening of norms, partly new norms adjust to developments. Sections that reinforce existing norms include types of rights claims, registration, adjudication and summons, resignation and right of denial, and appeal examinations. The new norms relate to the implementation of court decisions outside the territory of Indonesia, deadline for submitting summons to implement court decisions by the head of the District Court and clarify some regulations regarding hostagetaking (cost, time period and place of hostage).

Given the large number of parties with an interest in the Draft Law on Civil Procedure (hereinafter abbreviated to as RUU HAPer) and until now the HAPer has not been included in the 
National Legislation Program (Prolegnas), efforts to harmonize civil dispute resolution law have not yet been realized.

\subsection{Juridical, philosophical and sociological reasons for harmonizing civil dispute resolution laws.}

The implementation of harmonization of statutory regulations in Indonesia is a necessity. Yang urgently. Why it is said to be urgent, because the problem of legal development increasingly requires a holistic approach[22].

Formation of statutory regulations is the process of making laws and regulations which basically starts from planning, preparation, drafting regulations, formulation, discussion, ratification, promulgation and dissemination. In the era of globalization, the approach to handling development that still relies on sectoral will only result in patchy solutions, so that it does not solve various problems in the implementation of national development.

An important element of the harmonization of current laws and regulations in Indonesia is increasingly significant, amidst the increasingly complex situations and conditions, among others, the implementation of regional autonomy and the effects of globalization. The most prominent significance of steps to harmonize laws and regulations is to create legal certainty and guarantees for whoever has an interest.

Without harmonization of laws and regulations that are being drafted, it will create legal uncertainty, disorder and a sense of not being protected by the community. In this perspective, the problem of legal certainty will be perceived as a necessity which can only be realized through harmonization of laws and regulations. In this perspective, steps towards harmonization of statutory regulations can be carried out in two formulation steps, namely (i) harmonization of formulation policies (regulatory system) and (ii) harmonization of material (substance). The first point refers to the step in the formulation of the harmonization of the legal system, and the second point refers to the step in the formulation of the harmonization of norms (legal material)[23].

Harmonization of these provisions is to avoid the existence of statutory provisions that are not integrated in a legal system and lead to complicated case resolution processes and lead to legal uncertainty.

Juridically, the laws and regulations in Indonesia have the types and hierarchy as referred to in Law No. 12 of 2011 concerning the formation of laws and regulations. According to Article 7 paragraph (1), the types and hierarchy of statutory regulations are:

a. 1945 Indonesian Constitution

b. TAP MPR RI c. Laws / Government Regulations in Lieu of Law

d. Government regulations

e. Presidential decree

f. Provincial Regulation

g. Regency / City Regional Regulations

The formation of statutory regulations must be carried out based on the principles of forming good statutory regulations, including:

a. Clarity of purpose

b. Institutional or appropriate forming officials

c. Match between types, hierarchy, and content

d. Can be implemented

e. Efficiency

f. Clarity of formulation and

g. Openness.

One of the reasons for the formation of statutory regulations is the principle of being enforceable, this means that every formation of laws and regulations must pay attention to the effectiveness of these new laws and regulations on justice, certainty, legal usefulness in society both juridically, sociologically and philosophically. The juridical basis means that in these laws and regulations, considerations or reasons that describe the objectives of the formation of statutory regulations in this case are to solve legal problems or fill legal gaps, taking into account existing regulations, which will be changed, or which will be revoked. in order to fulfill the sense of justice and legal certainty of the community.

In juridical terms, it is time to harmonize the regulations for resolving civil disputes, considering that the existing regulations are still based on the laws of the Dutch East Indies, some of which have been revoked or amended since they are not in accordance with the minds of the Indonesian people. Besides, there are many Supreme Court Regulations which are products that are discusses judicial technical issues in the context of filling legal void or against the enactment of laws where there is no organic regulation whose structure resembles the formulation of laws as a source of judges in judicial practice and also for other law enforcers.

The juridical basis concerns legal issues relating to the substance or material being regulated so that it needs to be regulated by new laws and regulations. In general, the juridical reason for the formation of laws and regulations is that existing regulations cannot keep up with the development of society and technology, regulations that are not harmonious or overlapping resulting in disharmony of regulations, regulations that are lower than laws so that their effectiveness is weak, existing regulations exist legal void.

\section{CONCLUSIONS AND SUGGESTIONS}

\subsection{Conclusion}

Based on the discussion, the results of this study can be concluded: That civil dispute resolution law can be harmonized to realize legal unification since various kinds of regulations can cause multiple interpretations, is difficult to realize justice and legal certainty and cause disharmony of regulations. The 
existing civil procedural law provisions were a product of the Dutch East Indies government and could no longer accommodate the development of society, developments in science, technology and information. Juridically, the content of legal norms or rules of civil dispute resolution that currently applies is no longer accommodating the development of society so it needs to be evaluated, philosophically, the concepts and legal principles of new civil dispute resolution must be able to respond to the development of society and sociologically that the presence of new laws and regulations is not challenged by the public, therefore harmonization of civil dispute resolution law is needed in the context of unification of civil procedural law.

\subsection{Suggestion}

The government should immediately implement the new Indonesian Procedural Law and reflect the values that live in society and respond to the demands of society due to technological developments.

\section{REFERENCES}

[1] Otto Hasibuan, Criticism of Civil Procedural Law, Papers, Civil Procedural Law Conference, Jember 10 August 2018.

[2] Satjipto Raharjo, Law and Social Change, Bandung Alumni, 1983. Pg 127.

[3] CST. Kansil, Introduction to Indonesian Law and Legal Administration, Balai Pustaka, Jakarta, 1989, p. 36.

[4] Harum M. Husein, Environment, Problems in Management and Law Enforcement, Bumi Aksara, Jakarta, 1995, p. 168

[5] Takdir Rahmadi, Mediation of Dispute Resolution Through a Consensus Approach, Rajawali

Press, Jakarta, 2011, p. 1.

[6] Nurnaningsih Amriani, Alternative Mediation for Dispute Resolution in Courts,

Grafindo Persada, Jakarta, 2012, p. 16.

[7] ${ }^{1}$ Permono and Rosmidah, Application of Mediation Techniques as an Alternative to Settle land disputes in Kab. Muaro Jambi, Research Results, LPPM Jambi University, 2017, p. 40.

[8] M. Hosen, Implementation of the Small Claim Court System in Civil Cases to Realize Simple, Fast and Low Cost Judiciary in the Jambi District Court, Research Results, LPPM Jambi Univ, 2017, page 1.
[9] Tjukup et al, Fair Law Enforcement in Civil Case Examination in Courts Based on Pluralistic Civil Procedure Law, ADHAPER Civil Procedural Law Journal, Vol. 2 No. July 2-December 2016, p. 349

[10] AA Oka Mahendra, Harmonization of Legislation, Ministry of Law and Human Rights of the Republic of Indonesia, Jakarta, March 29, 2020.

[11]Sapto Budoyo, Concept of systemic steps to harmonization of law in the Formation of Legislation, CIVIS Scientific Journal, Vol. IV No. 2, July 2014, p. 607

[12] Kusnu Goesniadhie S., 2006. Harmonization of Law in the Perspective of Legislation (Lex Specialis a Problem). Surabaya: JPBooks Publisher, p. 10

[13] Sapto Budoyo, Concept of systemic steps to harmonization of law in the Formation of Legislation, CIVIS Scientific Journal, Vol. IV No. 2, July 2014, p. 609

[14] Merryman, John Henry, 1977. The Civil Law Tradition: An Introduction to the Legal System of Western Europe and Latin America, California: Stanford University Press. Pg 102

[15] Retnowulan Sutantio and Iskandar Oeripkartawinata, Civil Procedure Law in Theory and Practice, Mandar Maju, Bandung, 2008, p. 4.

[16] Efa Laila fakhriah, Kapita Selekta of Indonesian Civil Procedure Law, Mandar Maju, Bandung, 2019 , p. 5.

[17] Ishaq, Basics of Law, Revised Edition, Sinar Grafika, Jakarta, 2016, pg. 147.

[18] Kusnu Goesniadhie, Harmonization of the Legal System: Achieving Good Governance (Malang: Nasa Media, 2010), p. 11.

[19] Munir Fuady, Modern Law State Theory (Rechstaat), Bandung, 2009, p.9.

[20] Tjukup et al, Fair Law Enforcement in Civil Case Examination in Courts Based on Pluralistic Civil Procedure Law, ADHAPER Civil Procedural Law Journal, Vol. 2 No. July 2-December 2016, p. 349

[21] Efa Laela fakhriah, Kapita Selekta of Indonesian Civil Procedural Law, p. 59.

[22] Satjipto Rahardjo, Progressive Law; A Holistic Approach to Law, Progressive Law Journal, UNDIP Doctor of Law Program, 2005, p. 12.

[23] Kusnu Goessoesshi, 2006, Harmonization of Law in a Legislative Perspective; Lex Specialis a Problem, Publisher JP Books, Surabaya 